\title{
Ekstrak Betasianin dari Umbi Bit (Beta vulgaris) sebagai Pewarna Alami pada Sediaan Apusan Darah Tepi
}

\author{
${ }^{1}$ Islawati \\ ${ }^{2}$ Asriyani Ridwan \\ ${ }^{3}$ Rahmat Aryandi
}

1,2,3 Program Studi DIII Analis Kesehatan STIKes Panrita Husada Bulukumba, Indonesia

\section{Alamat Korespondensi:}

Islawati

Analis Kesehatan

STIKes Panrita Husada Bulukumba

085396551033

islawatich@gmail.com 


\begin{abstract}
ABSTRAK
Morfologi sel berupa eritrosit, trombosit dan leukosit merupakan bagian dari pemeriksaan Apusan Darah Tepi (ADT). Pemeriksaan ini mampu mengindetifikasi jenis dan jumlah dari leukosit dan trombosit bahkan mampu mengetahui adanya parasite. Di Indnesia yang memiliki iklim tropis, pewarnaan yang sering digunakan adalah pewarnaan Romanowsky yakni pewarnaan dengan menggunakan pewarnaan wright, giemsa, atau bahkan kombinasi dari kedua pewarnaan tersebut. Kualitas dari pewarnaan apusan darah tepi dapat dinilai dari morfologi eosinophil. Hal ini disebabkan karena kekhasan dari eosinophil serta jumlah yang cukup banyak dan mudah diamati. Selain itu, jaminan dari kevalidan suatu pemeriksaan ADT adalah kualitas dari hasil pewarnaannya. Tujuan dari penelitian ini adalah teramatinya morfolofi dari sel darah dari sediaan apusan darah tepi dengan menggunakan ekstrak betasianin dari umbi bit (Beta vulgaris) sebagai bahan pewarna alami pengganti giemsa. Jenis penelitian berupa eksperimen laboratory dengan metode perbandingan hasil pengamatan terhadap morfologi sel darah yang berupa eritrosit, trombosit dan leukosit dengan menggunakan giemsa sebagai gold standard dan ekstrak betasianin sebagai pewarna alami dari umbi bit. Penelitian ini menggunakan sampel darah vena yang diambil dan ditampung pada tabung EDTA lalu dibuat dalam bentuk sediaan apusan darah. Hasil pewarnaan dengan menggunakan giemsa menunjukkan granula terlihat cukup jelas dan terlihat merah muda dengan inti sel berwarna biru keunguan. ekstrak betasianin menunjukkan bahwa kualitas pewarnaan pada leukosit dan trombosit kurang baik dan eritrosit memiliki kualitas pewarnaan yang cukup baik dengan memperlihatkan warna oranye yang cukup jelas. Sehingga dapat ditarik kesimpulan bahwa ekstrak betasianin dari umbi bit dapat dijadikan sebagai alternative pewarna alami untuk sel eritrosit dari sediaan apusan darah tepi.
\end{abstract}

\title{
Kata Kunci: Betasianin, Umbi Bit, Eritrosit, Pewarnaan
}

\begin{abstract}
Morphology cell in the form of erythrocytes, platelets and leukocytes is part of the peripheral blood smear (ADT) examination. This examination is able to identify the type and number of leukocytes and platelets and is even able to detect the presence of parasites. In Indonesia, which has a tropical climate, the coloring that is often used is Romanowsky staining, namely staining using wright, Giemsa, or even a combination of the two colorings. The quality of the staining of the blood smear can be assessed from the morphology of the eosinophils. This is due to the uniqueness of eosinophils and their large number and easy to observe. In addition, the guarantee of the validity of an ADT examination is the quality of the staining results. The purpose of this study was to observe the morphology of blood cells from peripheral blood smears using betacyanin extract from beetroot (Beta vulgaris) as a natural dye substitute for Giemsa. The type of experimental research is in the form of a laboratory with a comparison method of observations on the morphology of blood cells in the form of erythrocytes, platelets and leukocytes using Giemsa as the gold standard and betacyanin extract as a natural dye from beetroot. This study used venous blood samples taken and stored in an EDTA tube and then made in the form of a blood smear. Staining results using Giemsa showed the granules were quite clear and looked pink with purplish-blue cell nuclei. Betacyanin extract showed that the quality of staining on leukocytes and platelets was not good and erythrocytes had a fairly good staining quality with a fairly clear color range. So it can be concluded that betacyanin extract from beetroot can be used as a natural alternative dye for erythrocyte cells from peripheral blood smear preparations.
\end{abstract}

Keywords: Betacyanin, Beetroot, Erythrocytes, Staining 


\section{PENDAHULUAN}

Kemampuan untuk menilai morfologi sel berupa eritrosit, trombosit dan leukosit serta mengetahui jumlah trombosit dan mengindentifikasi parasite membuat pemeriksaan apusan darah menjadi bagian penting rangkaian pemeriksaan dari hematologi. Hal yang menjadi penunjang keakuratan pemriksaan adalah hasil pewarnaan. ICSH International Council for Standarization in Haematology) merekmendasikan pewarnaan Romanowsky sebagai satu metode pewarnaan karena memberikan hasil yang memuaskan pada pemeriksaan apusan darah tepi. Metode pewarnaan yang menjadi bagian dari pewarnaan Romanowsky adalah Giemsa, Wright dan kombinasi keduanya, May-Grundwald, Jenner dan Leishman Umumnya di Indonesia, pewarnaan yang digunakan adalah giemsa karena pada iklim tropis giemsa lebih awet dibanding pewarnaan Romanowsky yang lain (Bain, 2017).

Pewarnaan Romanowsky memiliki kandungan pewarna kationik dan anionic yang berupa, azure $\mathrm{B}$ yang mampu memberikan warna ungu-biru atau biru pada inti sel, granula basophil, neutrophil dan nucleoprotein. Serta, pewarna anion asam dari eosin yang mampu memberikan warna oranye atau merah pada eritrosit. Namun, kelebihan ini juga sekaligus menjadi kekurangan dari pewarnaan ini karena kandungan dari methylene blue, eosin dan azur B yang bersifat tidak mudah terurai dan menjadi limbah yang berbahaya karena bersifat toksik (racun) serta mudah terbakar (Nugraha, 2015).

Kesadaran masyarakat akan pentingnya menjaga lingkungan yang semakin tinggi, menumbuhkan slogan back to nature menjadi alasan untuk mencari alternative metode pewarnaan yang ramah terhadap lingkungan yakni menggunakan pewarna alami. Misalnya memanfaatkan betasianin dari umbi bit (Beta vulgaris). Betasianin merupakan kelompok pigmen betalain yang berwarna merah hingga merah violet. Pigmen ini sangat signifikan dalam peentuan taksonomi tumbuhan tingkat tinggi. Perkembangan penggunaan pigmen betasianin tidak sepesat antosianin karena pigmen ini hanya dapat dijumpai pada beberapa family anggota ordo Caryophyllales dan bersifat mutual ekslusif dengan pigmen antosianin yang berarti pigmen antosianin dan betasianin tidak pernah dijumpai bersama-sama dalam satu tanaman. Betasianin sendiri merupakan pigmen kelompok plavonoid yang terikat dengan gula sehingga bersifat polar (Etim, 2019).

Senyawa betasianin memberikan perubahan warna pada $\mathrm{pH}$ tertentu sehingga dapat dijadikan sebagai indicator alami asam-basa. Kepekaan terhadap 
perubahan $\mathrm{pH}$ membuat betasianin sangat cocok dalam memberikan warna yang berbeda untusk setiap sediaan pemeriksaan eritrosit, leukosit. Tahun 2019 Emmanuel Asuquo Etim. Et. Al d menggunakan ekstrak tumbuhan Rosella untuk mewarnai apusan darah tepi hal tersebut menunjukkan bahwa betasianin yang terkandung dalam tumbuhan dapat digunakan sebagai pewarna dalam sediaan apusan darah tepi (Etim, 2019).

Umbi bit (Beta vulgaris) saat ini merupakan satu-satunya sumber pigmen betasianin yang diproduksi dalam skala besar. Beberapa sumber tanaman yang mengandung betasianin masih dalam proses eksplorasi untuk diteliti. Stabilitas dan resistensi betasianin lebih baik dari antosianin terhadap pengaruh $\mathrm{pH}$ dan suhu terutama pada $\mathrm{pH}$ asam rendah. Umbi bit (Beta vulgaris) dikenal sebagai sayuran dengan kandungan antioksidan tertinggi. Kandungan Betasianin dari Umbi bit (Beta vulgaris) lebih tinggi dibandingkan kandungan betasianin pada buah naga dan lbih stabil sehingga dapat dianggap bahwa umbi bit dapat menjadi sumber betasianin yang baik (Shofinita, 2020).

\section{METODE}

Penelitian ini merupakan penelitian deskriptif dengan melihat dan https://doi.org/10.37362/jkph.v6i2.644 membandingkan gambaran morfolgi dari sel darah yang berupa eritrosit, trombosit dan leukosit apusan darah tepi dengan menggunakan alternative pewarna alami dari ekstrak betasianin umbi bit dan giemsa sebagai gold standar. Metode pengambilan sampel berupa Simple Random Sapling yang mengambil 30 orang mahasiswa DIII Analis Kesehatan dari 80 orang mahasiswa tingkat dua Analis Kesehatan Panrita Husada Bulukumba. Penelitian ini diakukan di laboratorium kimia terapan Analis Kesehatan Stikes Panrita Husada Bulukumba pada bulan Agustus 2021.

Alat

Alat yang digunakan berupa mikroskop CX 21, objek glass, deck glass, tabung EDTA, tourniquet, rak tabung reaksi, rak pengecatan, pipet tetes, gelas kimia, gelas ukur, spoid $3 \mathrm{~mL}$,

\section{Bahan}

Bahan yang digunakan yakni giemsa, umbi bit, methanol 50\%, kapas, kasa, kertas saring, aquadest, kertas $\mathrm{pH}, \mathrm{HCl}$ pekat,

\section{Prosedur}

\section{Ekstraksi Betasianin}

ekstrak betasianin dari umbi bit dilakukan dengan melarutkan cacahan umbi bit yang telah dikeringkan selama $3 \times 24$ jam kedalam pelarut metanol-HCl (pH 5) dan direndam selama 2x24 jam dan Maserat yang diperoleh kemudian dipekatkan. 


\section{Pengambilan Sampel Darah Vena}

Sampel darah vena diambil dengan menggunakan spoid dan ditampung pada tabung vakum EDTA dilakukan dengan meletakkan lengan pasien dengan posisi lurus serta siku yangtidak dibengkokkan. lengan yang dipilih adalah lengan yang sering melakukan aktivitas. Tangan pasien diminta untuk dikepalkan kemudian dipasangkan tourniquet dengan jarak sekitar $\pm 10 \mathrm{~cm}$ di atas lipatan siku. Dipilih vena mediana cubiti. Lalu dibersihkan permukaan kulit tepat pada daerah yang akan diambil darahnya dengn menggunakan kapas alkohol $70 \%$ serta dibiarkan mengering (tanpa disentuh lagi). Menususk bagian vena dengan arah lubang jarum menghadap keatas serta sudut kemiringan $15^{\circ}$ antara kulit dan jarum. Tabung vakum ditekan agar darah terisap masuk ke dalam tabung. Selanjutnya tourniquet dilepaskan lalu pasien diminta untuk membuka kepalan tangan. Darah Biarkan mengalir masuk ke dalam tabung hingga selesa kemudian jarum ditarik dan diletakkan kapas pada bekas tusukan kurang lebih selama 2 menit. ketika darah telah berhenti mengalir, bagian ini lalu diplesterkurang lebih 15 menit.

\section{Pembuatan Preparat Apusan Darah Tepi \\ Darah pada tabung vakum EDTA} terlebih dahulu dihomogenkan agar selsel darah dapat bercampur dengan plasma darah, lalu darah diambil menggunakan pipet tetes kemudian diteteskan pada kaca preparat (obyek glass). Selanjutnya diletakkan objek glass yang lain pada sudut $25^{\circ}-30^{\circ}$ pada tetesan darah, llau ditarik lurus hingga ujung preparat dan terbentuk apusan yang tipis.

\section{Pewarnaan Preparat Apusan Darah}

\section{Tepi menggunakan Pewarnaan}

\section{Giemsa (Kontrol)}

Preparat apusan darah yang telah kering kemudian difiksasi dengan menggunakan metanol dengan cara diteteskan di atas preparat dengan menggunakan pipet tetes hingga seluruh permukaan preparat terbasahi dengan methanol. Methanol dibiarkan dibiarkan hingga menguap dan mengering. Lalu membuang sisa metanol. Selanjutnya preparat diwarnai degan menggunakan pewarna giemsa dan diteteskan hingga semua apusan tergenangi dan dibiarkan selama 15-30 menit. Preparat dibilas dengan air mengalir dan dikeringkan di udara.

\section{Pewarnaan preparat Apusan Darah} Tepi menggunakan pewarnaan ekstrak betasianin

Preparat apusan darah yang telah kering kemudian difiksasi dengan Jurnal Kesehatan Panrita Husada / 156 Vol, 6 No,2, September 2021 
menggunakan metanol dengan cara diteteskan di atas preparat dengan menggunakan pipet tetes hingga seluruh permukaan preparat terbasahi dengan methanol. Methanol dibiarkan dibiarkan hingga menguap dan mengering. Lalu membuang sisa metanol. Selanjutnya preparat diwarnai degan menggunakan pewarna alternative betasianin dan diteteskan hingga semua apusan tergenangi dan dibiarkan selama 15-30 menit. Preparat dibilas dengan air mengalir dan dikeringkan di udara.

\section{Pengamatan dibawah mikroskop}

Preparat yang telah jadi lalu diteteskan minyak imersi kemudian mengamati di bawah mikroskop pada perbesaran 100x.

\section{HASIL}

Konsentrasi ekstrak betasianin yang digunakan adalah $100 \%$ dengan gambaran sel darah yang ditunjukkan kurang jelas yaitu hasil pewarnaan pucat dan latar belakang berwarna orange. Adapun sel darah yang dapat diamati berdasarkan morfologi sel darah secara mikroskopik, kualitas pewarnaan yang cukup baik hanya pada eritrosit. Yang mana memiliki morfologi sel eritrosit berbentuk oval atau bulat dan dari samping terlihat seperti cakram (bikonkaf) dan sentral akromia (berwarna pucat oranye), tidak ada sisa zat pewarna sehingga nampak lapang pandang yang bersih, sel-sel tidak saling tumpang tindih. Namun kualitas pewarnaan trombosit dan leukosit kurang jelas sehingga gambaran yang diperoleh kurang baik. . Hasil pewarnaan dengan menggunakan giemsa menunjukkan granula terlihat cukup jelas dan terliha merah muda dengan inti sel berwarna biru keunguan

\section{PEMBAHASAN}

Pigmen betasianin dapat diekstrak dari tumbuhan yang digunakan sebagai pewarna alami. salah satu jenis tumbuhan yang menjadi sumber betasianin tertinggi adalah pada umbi bit (Beta vulgaris) yang saat ini pembudidayaannya mulai dikembangkan di Indonesia. Ekstraksi betasianin dengan menggunakan pelarut methanol-HCl pada pH 5 karena betasiani stabilpada $\mathrm{PH}$ tersebut dan pertambahan pH mempengaruhi warna yang dihasilkan. Dimana warna merah muda akan terdegradasi menjadi kuning seiring dengan pertambahan $\mathrm{pH}$. Penguapan pelarut dilakukan pada suhu ruang karena betasianin lebih stabil pada suhu $40^{\circ} \mathrm{C}$ dan pertambahan suhu membuat warna menjadi terdegradasi. Ekstrak yang dihasilkan diaplikasikan dalam pewarnaan apusan darah tepi dengan tujuan untuk melihat bagaimana kualitas apusan darah dengan mencermati morfologi sel darah yakni eritrosit, leukosit dan trombosit setelah diberikan pewarna alami betasianin. 
Pewarnaan sediaan apusan darah tepi menggunakan pewarnaan ekstrak betasianin pada konsentrasi ekstrak 100\%, memperlihatkan kualitas pewarnaan yang cukup baik adalah eritrosit. Hal ini disebabkan karena jumlah komponen senyawa betasianin dapat saling berinteraksi dengan sel eritrosit dan keasaman pada senyawa betasianin yang memiliki kecenderungan kesesuaian dengan keadaan $\mathrm{pH}$ pada eritrosit membuat interaksinya semakin baik. Pada keadaa tersebut, senyawa betasianin mampu berikatan dengan baik pada bagian permukaan sel eritrosit sehingga sel ini dapat teramati dengan baik dibawah miksorkop.

Berdasarkan hasil penelitian ini, ekstrak betasianin pada SADT tidak dapat mengamati trombosit dan leukosit. Hasil yang diamati berupa lapang pandang yang terlihat buram, pucat atau kecoklatan sehingga tidak didapatkan sel trombosit dan leukosit. Hal ini dikarenakan $\mathrm{pH}$ asam dari larutan mendegradasi membran sel trombosit dan leukosit, sehingga leukosit menjadi rusak dan tidak terwarnai, namun hanya sel ertirosit yang dapat terwarnai dalam keadaan larutan yang asam karena sel eritrosit lebih tahan terhadap asam. Pewarna giemsa memiliki sifat pewarna kation (basa) azure B yang berfungsi untuk mewarnai trombosit dan warna biru-ungu pada nukleuprotein, granula basofil dan granula neutrophil. Selain itu, pewarna giemsa juga memiliki sifat pewarna anion (asam) seperti Eosin $\mathrm{Y}$ yang dapat memberikan warna merah atau orange pada eritrosit dan granula eosinofil serta mewarnai inti sel (McKenzie, 2014).

Di Indonesia pewarnaan pada sediaan apusan darah tepi umumnya menggunakan giemsa. Hal ini karena giemsa sangat baik dalam mengidentifikasi sel granulosit serta sel darah yang lain. Pada pewarnaan giemsa memberikan gambaran inti yang jelas, dalam membedakan komponen dari basofili serta eosinophil yang erasal dari sel myeloid dan limfoid. Selain itu giemsa juga tahan terhadap iklim tropis dan sangat baik ketika mempelajari jenis parasite darah Riswanto, 2013).

\section{KESIMPULAN DAN SARAN}

Ekstrak betasianin dari umbi bit yang digunakan untuk mewarnai sediaan apusan darah tepi menunjukkan bahwa eritrosit dapat teridentifikasi dengan menghasilkan hasil pewarnaan latar pucat dan eritrosit yang berwarna orange sehingga cukup baikuntuk pewarnaan eritrosit namun tidak dapat mewarnai trombosit dan leukosit sehingga ekstrak betasianin memiliki potensi untuk digunakan sebagai pewarna alternatif pada pengamatan sel darah merah terkhusus eritrosit 
Sebaiknya melakukan penelitian lebih lanjut mengenai penambahan komponen zat pewarna pada ekstrak betasianin yang ingin dijadikan sebagai pewarna terhadap sel leukosit dan trombosit baik dari bahan alam maupun dengan mengkombinasikannya dengan pewarna eosin ataupun metilen blue sehingga hasil pewarnaannya mendekati warna dari giemsa. Sebaiknya dalam penelitian selanjutnya melakukan netralisasi $\mathrm{pH}$ hingga mendekati $\mathrm{pH}$ fisiologi darah.

\section{DAFTAR PUSTAKA (REFERENSI)}

Bain, Barbara Jane. 2017. Blood Cells: A Practical guide. John Wiley \& Sons.

Etim, E.A., Chagwa, F.E., Obeagu, E.I., Udokang, A.A. 2019. Staining effect of methanolic extract of hibiscus sabdariffa calyx on thin peripheral blood smear. Journal of Diseases, 6(1):1-6.

Freund, M. 2013. Heckner Atlas Hematologi, Jakarta, Buku kedokteran. EGC.

Gilang, Nugraha. 2015. Panduan Praktikum Laboratorium Hematologi Dasar. Jakarta. Trans Info Media

Khoo, H.E., Azlan, A., Tang, S.T., Lim,S.M. 2017. Anthocyanidins and anthocyanins: colored pigments as food, pharmaceutical ingredients, and the potential health benefits. Food Nutr. Res. $61,1654-1661$.

Kiswari, R, 2014. Hematologi Dan Transfusi. Jakarta: Erlangga

McKenzie, S.B. 2014. Clinical Laboratory Hematology. Pearson Education Inc. New Jersey.
Nanda, R. W. 2014. Produksi Serbuk Pewarna Alami Bit Merah (Beta vulgaris L.) dengan Metode Oven Drying. Semarang: Fakultas Teknologi Pangan.

P. H., Chong., Yusuf,Y. A., Aziz M. G. 2013. Evaluation of Solvent extraction of Amaranth betacyanins using multivariate analysis. Journal Food Research Journal 21(4):1569-1573

Thamrin, Hilma Yuniar. 2017. Hematologi III. Bahan Ajar. Kendari. D3 Analis Kesehatan

Riswanto. $2013 . \quad$ Pemeriksaan Laboratorium Hematologi. Alfamedia dan Kanal Medika, Yogyakarta.

Santos, D. T., Cavalcanti, R. N., Rostagno, M. A., Queiroga, C. L., Eberlin, M. N., Meireles, M. A. A. 2013. Extraction of Polyphenols and Anthocyanins from the Jambul (Syzygium cumini) Fruit Peels. Food and Public Health, 3(1), 1220.

Shofinita, Dian., Yazid Bindar; Ardiyan Harimawan. Arwinda A. J., Mifta F. 2020. Production of Bioactive Materials for Food Additives from Dragon Fruit Skin Extracts: Effect of Pretreatment and Extraction Methods. Indonesian Journal of Chemical Research.,8 (1), 43-50, 2020

Woo, K. K., F. H. Ngou., L.S Ngo., W. K. Soong., P. Y. Tang. 2011. Stability of Betalain Pigment from Red Dragon Fruit (Hylocereus polyrhizus). American Journal of Food Technology.ISSN.15574571/do:10.3923/ajft.201 

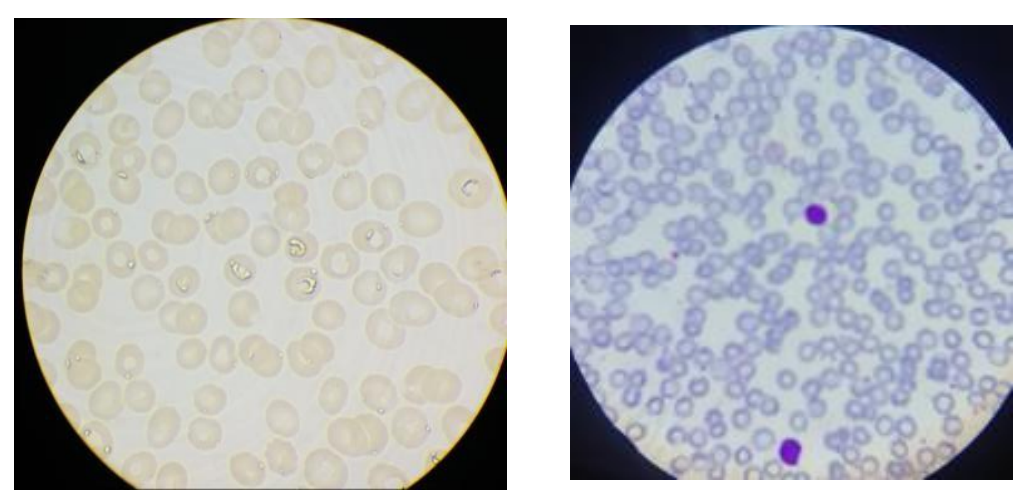

Gambar:

1. Hasil Pengamatan Sediaan Apusan Darah Tepi Pewarnaan Ekstrak Betasianin Konsentrasi $100 \%$.

2. Hasil Pengamatan Sediaan Apusan Darah Tepi Pewarnaan giemsa 